\title{
Histopathology of Yearling Sockeye Salmon (Oncorhynchus nerka) Infected with Infectious Hematopoietic Necrosis (IHN)*
}

\author{
William T. YASUTAKE \\ National Fisheries Research Center Building 204, Naval Support Activity, \\ Seattle, Washington 98114, USA
}

(Received August 28, 1979)

\begin{abstract}
Infectious hematopoietic necrosis (IHN) is generally believed to be a virus disease of very young salmonids. In recent years there have been increasing numbers of unpublished reports that this disease has been occurring uncharacteristically in fish as old as 7-14 months. Sockeye salmon (Oncorhynchus nerka) of this age the histological changes were not severe. Intestinal tract granular cells thought to be pathognomic in young fish were conspicuously absent. Kidney imprints showed necrobiotic bodies however, and subtle changes were observed in the spleen and kidney hematopoietic tissue.
\end{abstract}

\section{Intorduction}

Infectious hematopoietic necrosis (IHN) virus disease has been a very serious problem in several species of salmonids. Until 1973 it had been reported only in Canada and the United States; it is enzootic in many areas along the Pacific coastal region from Alaska to northern California (GRISCHKOWSKY and AMEND, 1976; WiLliams and AMEND, 1976; AMEND et al., 1973). This virus disease was also diagnosed in Northern Japan as early as 1972 , although not formally reported and confirmed as IHN until a later date (KIMURA and Awakura, 1977; SANo et al., 1977). The disease has been experimentally induced in most species of salmonids, but epizootic outbreaks in feral and hatchery populations have been reported only in chinook salmon (Oncorhynchus tshawytcha), sockeye salmon and kokanee $(O$. nerle $a)$, and rainbow and steelhead trout (Salmo gairdneri). More recently IHN has been confirmed in yamabe (landlocked $O$. masou) (KIMURA and AWAKURA, 1977) and in chum salmon (SANO et al., 1977).

Several histopathological descriptions of IHN YASUTAKE, 1970, 1975; YASUTAKE and AMEND,

* Presented at a special meeting of the Japan Research Group of Fish Pathology in Tokyo, Japan April 1, 1979.
1977 ; YASUTAKE et al., 1965) concerned young trout and salmon up to 3-4 months old. In recent years there have been increasing numbers of unpublished reports that this virus infection has been occurring uncharacteristically in fish as old as 7-14 months ( $\mathrm{H}$. WOLF, personal communication). Clinical and histopathological manifestations in these older fish with IHN have been unlike those usually associated with IHN in fry and fingerlings. This report compares different aspects of the "typical" clinical, histopathological and hematological changes that occur in young salmonids with those that occur in 7-14 month old sockeye salmon infected with IHN virus.

\section{Materials and Methods}

The histological and hematological materials described here include diagnostic specimens received from a local hatchery and experimentally exposed fish. Group A consisted of sockeye salmon fingerlings $65-70 \mathrm{~mm}$ long and 7-8 months old, brought to the National Fisheries Research Center because the hatchery was experiencing an unusually high mortality. Group B consisted of sockeye salmon 100-112 $\mathrm{mm}$ long and 10-14 months old sockeye salmon, of the 1975 brood, from the Wenatchee River, Washington.

Two lots of 15 fish each in group B were exposed to the virus by placing them in 
dechlorinated domestic water $\left(\right.$ at $\left.10^{\circ} \mathrm{C}\right)$ containing about $10^{5}$ TCID $50 \mathrm{ml}$ for 15 minutes; after this exposure, the normal water flow was resumed (AMEND and NELSON, 1977). Mortality was recorded daily until the end of the 27-day experiment. Moribund fish were periodically examined to confirm IHN infection. Samples from the kidney, liver, spleen, digestive tract, and gill were fixed in Bouin's solution for histological examination. Anterior kidney imprints and peripheral blood smears (from the severed caudal peduncle) were taken from all moribund fish, fixed in absolute methanol for 5 minutes, air dried and then stained with Leishman-Giemsa as outlined by WEDEMEYER and YASUTAKE (1977).

\section{Results}

Grossly, the moribund fish in both the A and $B$ groups lacked many of the characteristics of IHN infection, such as anemia, distention of the abdomen with ascites and fecal casts. A few fish in group A showed slight exophthalmos, scoliosis, and dark coloration; however, none of the moribund fish in group B exhibited these signs.

An initial histological examination of fish in group A indicated only minor tissue changes and did not show the extensive histopathological changes usually associated with IHN, as described by AMEND and YASUTAKE (1972) and YASUTAKE (1970, 1975). However, kidney imprints from these 7-8 months old sockeye salmon revealed necrobiotic bodies (Figs. 1 and 2) that resembled those previously described in IHN infected salmonids (AMEND and Chambers, 1970 ; and AMEND and SMith, 1975). They numbered from a few to several and were not abundant; nor were there any "vacuolated" macrophage-like cells as noted by previous investigators.

Detailed examination of the anterior kidney and spleen tissues of fish of the A group revealed subtle areas of focal cellular degeneration and necrosis (Figs. 3 and 4). In the kidney, hematopoietic tissue was involved and, in the tubular epithelium, intracytoplastic hyaline droplets were present as well (Fig. 4). It was difficult to determine the specific cell or cells involved in the area of the degenerative and necrotic changes. A moderate amount of sloughing of the epithelial lining of the small intestine also occurred, particularly in the area just posterior to the ceca. Clinically, however, none of these fish produced fecal casts.

The experimentally exposed (B) group, exhibited many of the same histological alterations shown by the naturally exposed (A) group. However, blood smears from several fish in group B showed monocytes with vacuolated cytoplasm, which were not seen in the blood of group A fish. The vacuoles in these cells were extremely small, giving the cytoplasm a foamy appearance (Fig. 5). Kidney imprints of many of these 10-14 months old fish had one to several necrobiotic bodies. Hyaline droplets in the kidney epithelium were also present (Fig. 6); the spleen showed degenerative changes and a marked lack of lymphoid cells (Fig. 7); and sloughing of the epithelium was again evident in the small intestine (Fig. 8).

\section{Discussion}

Among sockeye salmon infected with IHN, there were several notable histological differences between the fish 7-14 months old and younger fish (yolk sac fry to 3-4 months of age).

Previous work has shown that in the younger fish there are usually extensive histopathological changes involving the kidney, spleen, pancreas, liver, and granular cells of the digestive tract (YASUTAKE, 1975). In the present study the histological alterations were apparently not severe.

The granular cells, located in the wall of the intestinal tract along the stratum granulosum, are found in fish 3-4 months old but do not usually occur in younger fish. These cells are apparently highly susceptible to IHN virus and their necrosis is considered to be pathognomonic for IHN (YASUTAKE, 1970, 1975). Therefore, it was surprising that no granular cell involvement (Fig. 8) was detected in the sockeye salmon examined in the present study.

The occurrance of hyaline droplets in the kidney tubule epithelium (Figs. 3 and 6) was 
in marked contrast to their absence in fish less than 3-4 months old. In these younger fish renal elements of the kidney showed no pathological involvement until massive necrosis in the hematopoietic tissue became evident in the kidney.

Several investigators have suggested that necrobiotic bodies are lymphocytes (WATSON, 1956; AMEND and CHAMBERS, 1970), immature erythrocytes PARISOT et al., 1965), or karyolytic debris of disintegrating neutrophils (AMEND and SмIтH, 1975). The information available to date provides encouraging evidence that the presence of necrobiotic bodies may be used for the presumptive diagnosis of IHN. For a definitive diagnosis, virological techniques are, of course still necessary. Kidney imprints can very readily be made in the field if a rapid presumptive diagnosis is needed.

It is clear from the present results that a pathogenesis study of older juvenile salmonids infected with IHN is necessary to fully understand the development of the disease.

\section{Acknowledgments}

I thank Drs. D. M. Mulcahy and G. Wedemeyer for their helpful comments and R. A. Goodwill and R. Nelson for their technical assistance.

\section{References}

Amend, D.F. and V.C. Chambers (1970): The morphology of certain viruses of salmonid fishes. II. In vivo studies of infectious hematopoietic necrosis virus. J. Fish. Res. Board Can., 27(8), 1385-1388.

AMEND, D. F. and J.R. Nelson (1977): Variation in the susceptibility of sockeye salmon Oncorhynchus nerka to infectious hematopoietic necrosis virus. J. Fish Biol., 11, 567-573.

Amend, D. F. and L. Smith (1975): Pathophysiology of infectious hematopoietic necrosis virus disease in rainbow trout: hematological and blood chemical changes in moribund fish. Infect. Immun., 11(1), 171-179.

Amend, D. F., W. T. Yasutake, J. L. Fryer, K. S. Plicher and W.H. Wingfield (1973): Infectious hematopoietic necrosis (IHN). In W. A. Dill (ed.) Symposium on the major communicable fish diseases in Europe and their control, p. 80-87. Eur. Inland Fish. Advis. Comm. Tech. Pap. 17, Suppl. 2.
Grischkowsky, R. S. and D. F. AMEND (1976): Infectious hematopoietic necrosis virus: Prevalence in Alaskan sockeye salmon (Oncorhynchus nerka). J. Fish. Res. Board Can., 33(1), 186-188.

Kimura, T. and T. AwakUra (1977): Current status of disease of cultured salmonids in Hokkaido, Japan. In Proceedings of The International Symposium on Diseases of Cultured Salmonids, p. 124-160. Tavolek, Inc.

MCInTYRE, J.D. and D.F. Amend (1978): Heritability of tolerance for infectious hematopoietic necrosis in sockeye salmon (Oncorhynchus neka). Trans. Am. Fish. Soc., 107(2), 305-308.

Parisot, T. J., W. T. Yasutake, and G. W. KlontZ (1965): Virus diseases of the Salmonidae in western United States. I. Etiology and epizootiology. N. Y. Acad. Sci., 126, 502-519.

Sano, T., T. Nishimura, N. OKamoto, T. YamaMAKI, H. HANADA and Y. WATANABE (1977): Studies of viral diseases of Japanese fishes. VI. Infectious hematopoietic necrosis (IHN) of salmonids in the mainland of Japan. J. Tokyo Univ. Fish. 63(2), 81-85.

Waston, M. E., R. W. Guenther and R. D. Royce (1956): Hematotology of healthy and virus diseased sockeye salmon, Oncorhynchus nerka. Zoologica, N. Y. 41(1), 27-38.

Wedemeyer, G.A. and W.T. Yasutake (1977): Clinical methods for assessing the effect of environmental stress on fish helth. U.S. Fish Wildl. Serv. Tech. Paper 89. 18 pp.

Williams, I. V. and D.F. Amend (1976): A natural epizootic of infectious hematopoietic necrosis virus disease in sockeye salmon fry (Oncorhynchus neka) at Chilko Lake, British Columbia. J. Fish. Res. Board Can., 33 1564-1567.

Yasutake, W. T., T. J. Parisot and G. W. Klontz (1965): Virus diseases of the Salmonidae in western United States. II. Aspects of pathogenesis. Ann. N. Y. Acad. Sci., 126, 520-530.

YASUTAKE, W. T. (1970): Comparative histopathology of epizootic salmonid virus diseases. In S.F. Snieszko (editor), A symposium on diseases of flshes and shellfishes, p. 341-350. Am. Fish. Soc., Spec. Publ. No. 5.

Yasutake, W. T. and D. F. Amend (1972): Some aspects of the pathogenesis of infectious hematopoietic nucrosis. J. Fish. Biol., 4(2), 261-264.

YASUTAkE, W.T. (1975): Fish virus diseases: clinical, histopathological and comparative aspects. In A. E. Ribelin and G. Migani (editors), The Pathology of Fishes, p. 246-271. Univ. Wis. Press, Madison, Wis. 


\section{伝染性造血器壞死症 (IHN) 亿感染したベニマス (Oncorhynchus nerka) 一才魚の病理組織}

\footnotetext{
伝染性造血器壊死症 (IHN) は一般にはごく若いサケ科魚類の疾病と考えられているが，最近，7-14 月 令の魚に症状の余り顕著でない感染が起っているとの未公表の報告が增えつつある。これらを調べたところ, IHN 特有の症徵と考えられている腸管の顆粒細胞は全く認められなかった。しかし, 類壊死細胞が腎蔵の捺 印標本中に認められ，また，脾臓および腎臓の造血組織にも僅かながら病変が観察された。

(本稿は昭和 54 年 4 月 1 日に開催の総会特別講演要旨である)
}

\section{Explanation of Figures}

Figs. 1-4. 7-8 months old sockeye salmon naturally infected with IHN.

Fig. 1. Kidney imprint. Note necrobiotic body (arrow). Leishman-Giemsa.

Fig. 2. Kidney imprint. Note necrobiotic bodies (arrows). Leishman-Giemsa.

Fig. 3. Kidney section, showing area of focal degeneration and necrosis (arrow). H \& E.

Fig. 4. Spleen section, showing area of focal necrosis involving few cells (arrows).

Figs. 5-8. 10-13 month old sockeye salmon experimentally infected with IHN.

Fig. 5. Peripheral blood smear. Note large cell in the center, probably a monocyte, showing foamy cytoplasm. Leishman-Giemsa.

Fig. 6. Kidney section. Note the hyaline droplets in the epithelium of tubules (arrows). H \& E.

Fig. 7. Spleen section. Note some degeneration and necrosis and the lack of lymphoid cells. H \& E.

Fig. 8. Intestine just posterior to the ceca. Sloughing of the epithelial layer of the intestine is clearly evident. H \& E. 


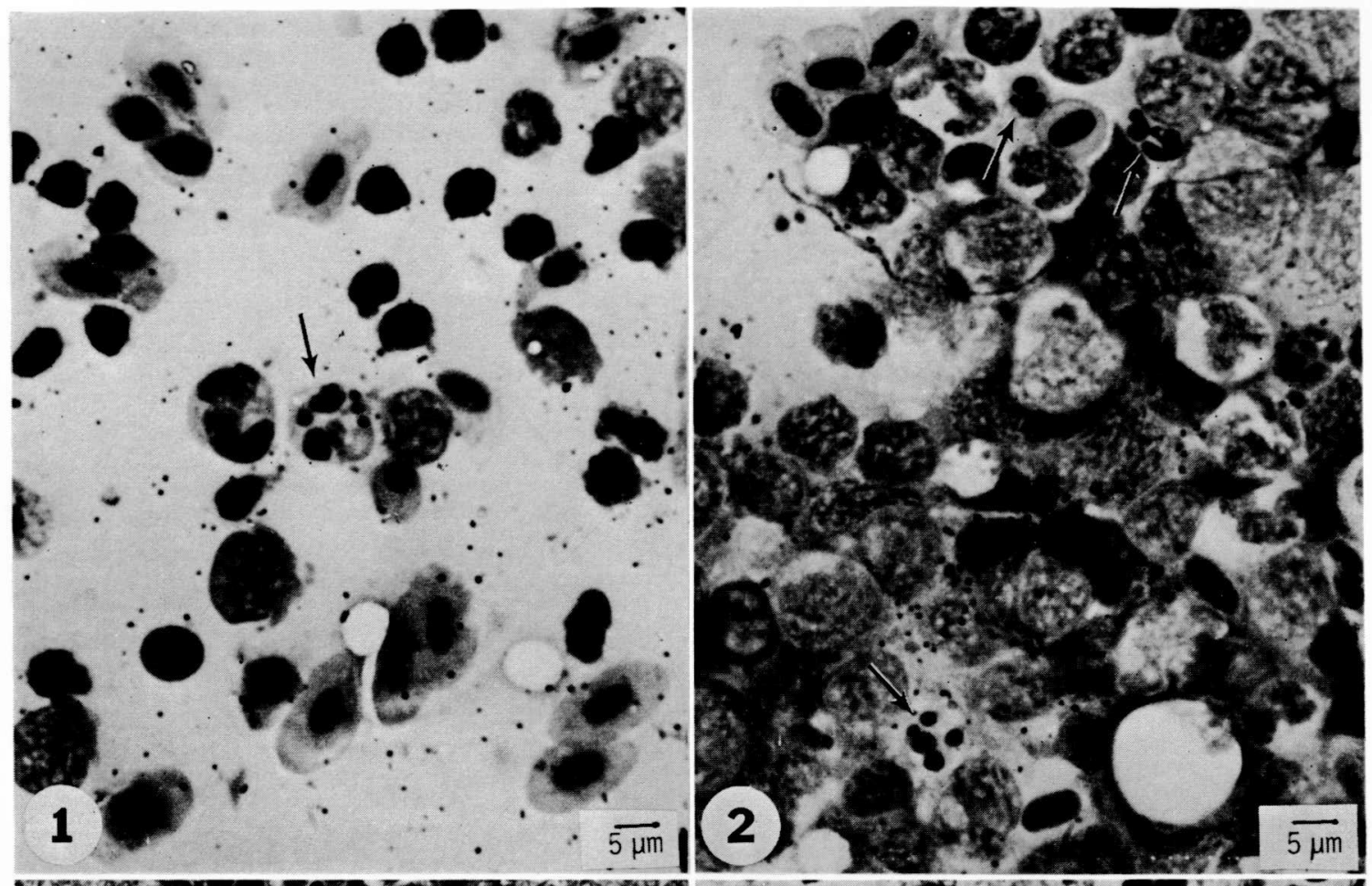

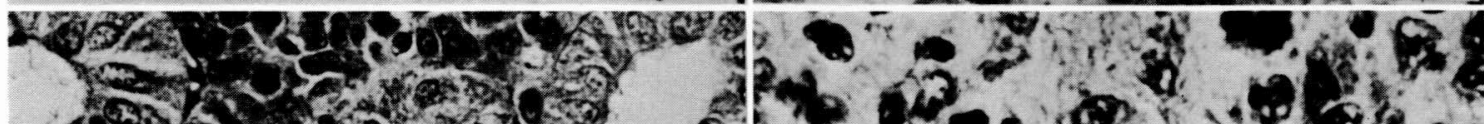

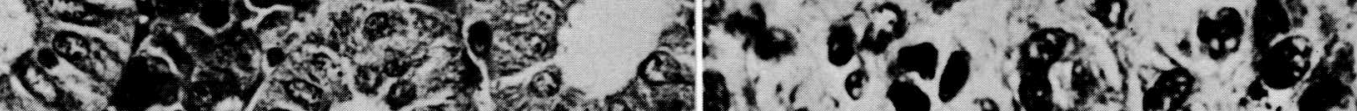

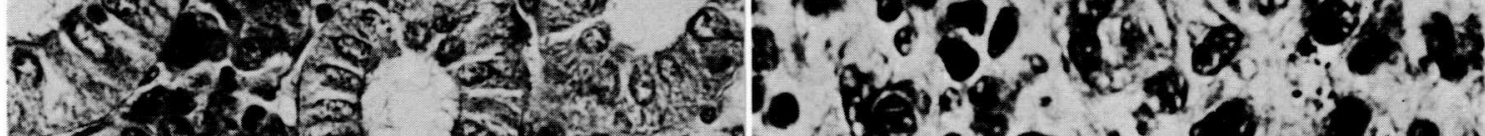

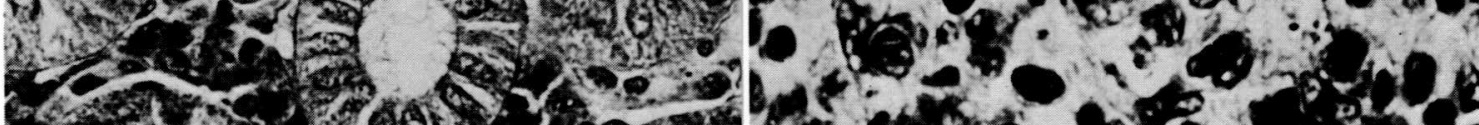

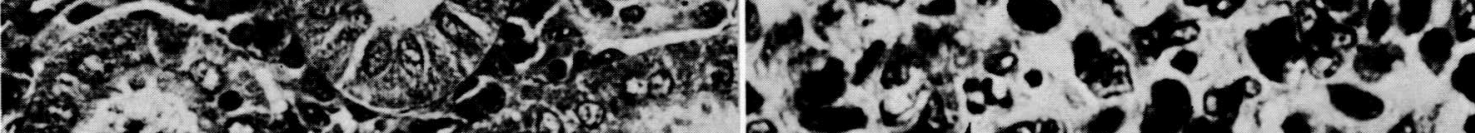

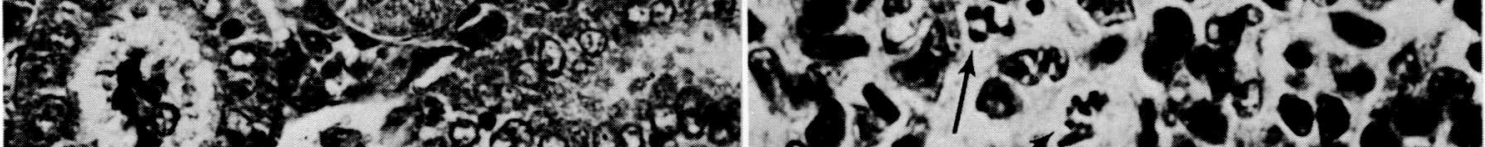

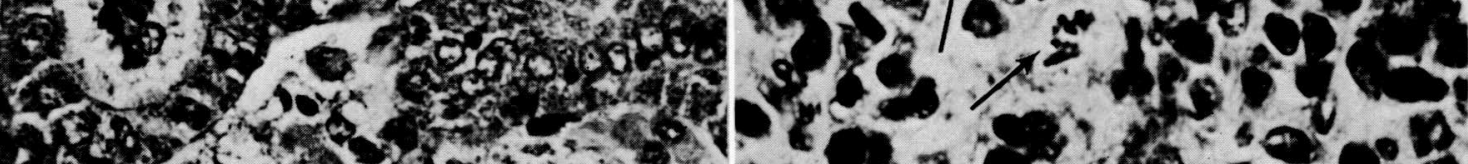

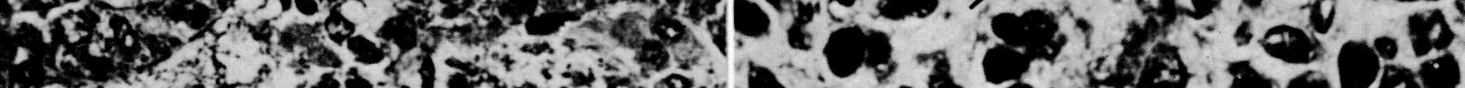

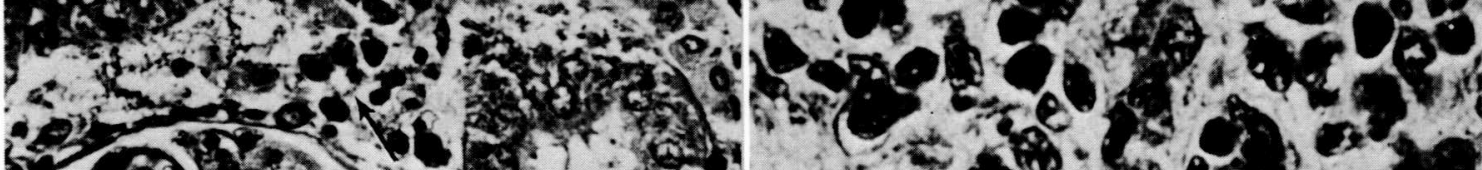

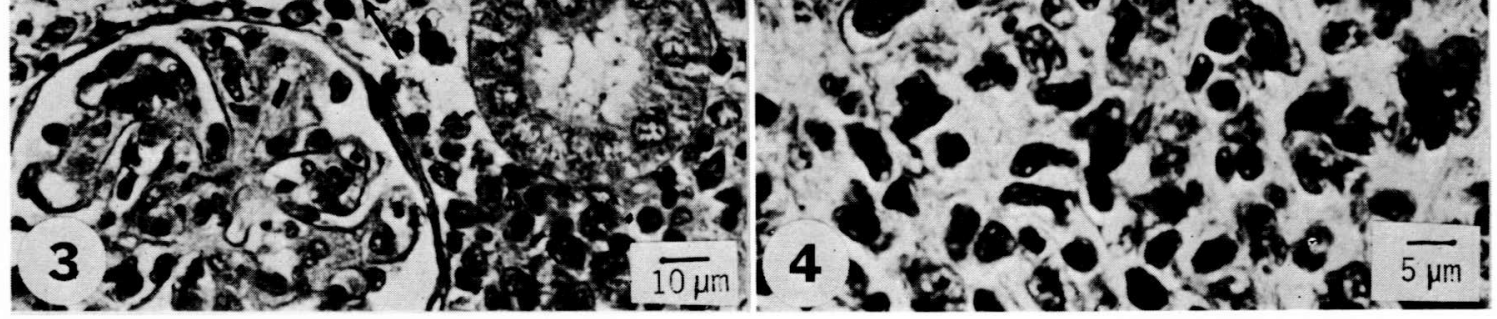




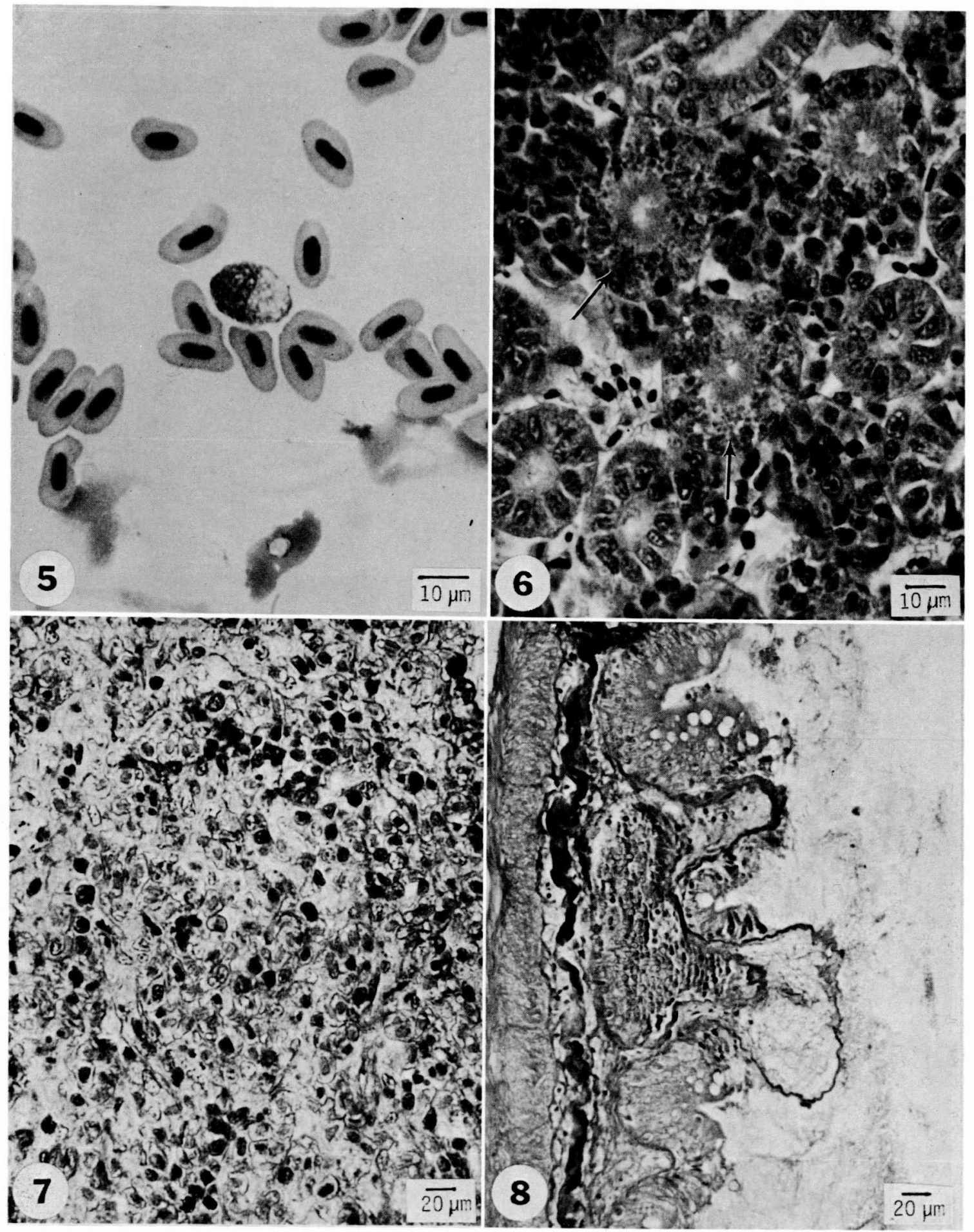

